\title{
Öğretmen Algılarına Göre Okul Öncesi Yöneticilerinin Etik Liderlik Davranışları: Antalya İli Örneği
}

\author{
DOI: 10.26466/opus. 892148 \\ * \\ Begümhan Yüksel * \\ * Dr. Öğr. Üyesi, Akdeniz Üni., Temel Eğitim Böl., Antalya/Türkiye \\ E-Posta: : begumhanyuksel@gmail.com ORCID: 0000-0002-0869-9157
}

Öz

Okul öncesi öğretmenlerinin mesleki memnuniyetlerini artırmada okul yöneticilerinin önemli rol ve sorumluluğu olduğu dikkate alınarak bu araştırmada, okul öncesi eğitim kurumlarında görev yapan kurum yöneticilerinin etik liderlik davranışların incelemek amaçlanmıştır. Betimsel tarama modelinde gerçekleştirilen bu araştırmaya 2020-2021 eğitim-öğretim yılında Antalya il merkezindeki okul öncesi eğitim kurumlarında görev yapan 163 öğretmen dâhil edilmiştir. Araştırmada verilerinin toplanmasında demografik bilgi formu ve "Etik Liderlik Ölçeğ $i$ " kullanılmıştır. Araştırmada verilerin analizinde okul öncesi öğretmenlerinin, yöneticilerin etik liderlik davranışına ilişkin algı düzeylerini saptamak için aritmetik ortalamaya, standart sapmaya bakılmış, yaş ve mesleki kıdem değişkenlerine ilişkin ortalamalar arasındaki farkın belirlenmesinde t-testi analizi yapılmıştır. Araştırmada okul öncesi eğitim kurumlarında görev alan yöneticilerin, iletişimsel etik, iklimsel etik, karar vermede etik ve davranışsal etik bağlamında orta düzeyde etik liderlik davranışlarına sahip oldukları belirlenmiştir.

Anahtar Kelimeler: Okul Öncesi Öğretmeni, Okul Yöneticisi, Etik Liderlik 


\title{
Ethical Leadership Behaviors of Preschool Managers According to Teacher Perceptions: Case of Antalya
}

*

\begin{abstract}
Considering that school administrators have an important role and responsibility in increasing the professional satisfaction of preschool teachers, this study aims to examine the ethical leadership behaviors of institution administrators working in pre-school education institutions. 163 teachers working in pre-school education institutions in the city center of Antalya in the 2020-2021 academic year were included in this research carried out in the descriptive survey model. Demographic information form and "Ethical Leadership Scale" were used to collect data in the study. In the analysis of the data, the arithmetic mean and standard deviation were examined in order to determine the perception levels of the preschool teachers regarding the ethical leadership behavior of the administrators, and the t-test analysis was performed to determine the difference between the means for age and professional seniority variables. In the study, it was determined that administrators working in preschool education institutions have moderate ethical leadership behaviors in the context of communicative ethics, climatic ethics, ethics in decision making and behavioral ethics.
\end{abstract}

Keywords: $\quad$ Preschool Teacher, School Administrator, Ethical Leadership 


\section{Giriş}

Erken çocukluk dönemi 0-8 yaş aralığında bulunan çocukların hızlı gelişim gösterdikleri, öğrenme kapasitelerinin en yüksek düzeyde olduğu ve kişilik özelliklerinin şekillendiği dönem olması sebebiyle kritik öneme sahiptir. Bu dönemde çocukların gelişiminde ailelerin yanı sıra okul öncesi eğitim kurumlarında aldıkları eğitimde aktif rol alan okul öncesi öğretmenlerinin de etkisi büyüktür. Bu bağlamda okul öncesi öğretmenlerinin mesleki motivasyon ve memnuniyet düzeylerinin okul öncesi eğitimin niteliğini etkileyen bir faktör olduğunu söylemek mümkündür.

Öğretmenlerin mesleki memnuniyetlerini ve başarılarını, dolayısıyla da okullarda hedeflenen eğitim başarısını etkileyen en önemli faktörlerden biri kurum yöneticilerinin liderlik özellikleridir. Kurumların başarılı şekilde yönetilebilmesi için yöneticilerin liderlik becerilerine sahip olması gerekmektedir (Bridge, 2003). Araştırmalara (Çetin, 2016; Demirtaş ve Akdoğan, 2015; Gülcan, Kılınç ve Çepni, 2012; Güllü, 2009; Neubert, Carlson, Kacmar, Roberts ve Chonko, 2009; Ruiz-Palomino, Ruiz-Amaya ve Knörr, 2011) göre çalışanların iş doyumlarını, çalışma performanslarını ve kurumlarına bağlılıklarını etkileyen en önemli faktörlerden biri etik liderlik davranışlarıdır. Turnan'ın (2007:7) Sergiovanni'den aktarımına göre okul yönetimindeki liderliğin kalbi, etik liderlik davranışlarıdır.

Evrensel olarak kabul edilen etik liderlik değerleri genel olarak, liderlerin kararlar alırken ve bu kararları uygulamaya aktarırken başkalarının haklarına, onuruna saygılı davranmayı, demokratik yönetim anlayışına ve güçlü iletişim becerilerine sahip olmayı ifade etmektedir (Ciulla, 2004; Yılmaz, 2008). Etik liderler, adil kararlar veren, önyargısız ve tarafsız, çalışanları her konuda bilgilendiren, şeffaf, çalışanların haklarını gözeten, etik kuralları içselleştirmiş, dürüst, güvenilir, şefkatli, sabırlı, hoşgörülü, verdiği sözü tutan, yalan söylemeyen, dedikodu yapmayan, başkalarına saygılı liderlerdir (Brown, Trevino, ve Harrison, 2005; Brown ve Trevino, 2006; Mendonca, 2001; Zhu, May ve Avolio, 2004). Resick, Hanges, Dickson ve Mitchelson 
(2006) 59 ülkede etik liderlik kavramını inceledikleri kültürlerarası araştırmada etik lider davranışlarını karakter ve doğruluk, etik farkındalık, topluluk / insan odaklılık, motive edicilik, teşvik edicilik, güçlendiricilik ve etik hesap verebilirliği olmak üzere altı boyutta toplandığı ifade edilmektedir.

Yılmaz (2005), okul yöneticilerinin etik liderlik düzeylerini iletişimsel etik, iklimsel etik, karar vermede etik ve davranışsal etik olmak üzere dört grupta ele almıştır. Yöneticinin sabırlı ve alçak gönüllü olması, çalışanlara adaletli, sevgi, şefkat ve saygıyla yaklaşması, merhametli olması, yapılan hizmetlerden dolayı minnet duygusu beslemesi "iletişimsel etik"; kendi işlerini sorumluluk duygusu içinde yaparak öğretmenleri teşvik etmesi, öğretmenlerin çalışmaları için, tartışmalar için uygun, özgür ortam hazırlaması, farklı düşüncelere saygı duyması, okulun kurallarını doğru bir şekilde oluşturması ve öğretmenlerin başarısını adaletli bir şekilde ödüllendirerek mesleki etkinliğini artırmaya yönelik çaba içerisinde olması "iklimsel etik"; okul yöneticisinin okulda yapılan işlerde ölçüyü belirlemesi, çözümler üretmede sistemli yaklaşması, dini, politik, ekonomik konularda kazanç sağlamaya yönelik çalışmalar yapmaması, okulda ortak alınan kararları, etkili biçimde uygulaması, kötü sayılabilecek alışkanlıklara sahip olmaması ve davranışlarının sınırlarını bilmesi "karar vermede etik" ve son olarak doğru sözlü, dürüst olması, yalan söylememesi ve içinde bulunduğu toplumun değerlerine saygı göstermesini "davranışsal etik" olarak açıklamıştır.

Erdoğdu, Umurkan ve Kuru'ya (2013) göre günümüzde bürokratik ve yasal otoriteden çok, değer, inanç, duygu ve güven temelli yeni bir liderlik biçimine ihtiyaç duyulmaktadır. Bu bağlamda okul öncesi eğitim kurumlarında yöneticilik yapan liderlerin öğretmenleri karar alma sürecine katma, öğretmenler üzerinde güçlü bir etki oluşturma, öğretmenlerin iş amaçlarını gerçekleştirmelerine yardım etme, ahlaki davranışlarıyla örnek olma, etkili iletişim kurma, ahlaki bir vizyon geliştirme gibi özelliklere (Greenfield, 1991: akt. Çelik, 2012; Moorhouse, 2002; Wekesser, 1995) sahip olması gerektiğini söylemek mümkündür. 
Etik olmayan liderlik davranışlarının kurum içinde işbirliği, iletişim, yaratıcılık, huzur ve güveni azaltması sebebiyle (Alatlı, 1999; akt. Tombak ve Bakan, 2014: 98), yöneticilerin etik davranışları o kurumdaki çalışanların iş doyumu, iyi oluş, örgütsel adalet, örgütsel vatandaşlık davranışı, örgütsel bağlllık gibi pek çok faktörü etkilemektedir (Bahar, 2019; Mayer, Kuenzi, Greenbaum ve Salvador, 2009).

Etik liderlik, etik değerlere ve ilkelere dayalı ilişkileri sürdürmeyi ve bunları ön planda tutmayı ön gören bir liderliktir (Erdoğan, 2007: 48). Sosyal öğrenme teorisi (Bandura and Walters, 1986) bağlamında düşünüldüğünde kurum yöneticilerinin etik liderlik davranışları sergilemesi, etik liderlik davranışlarıyla çalışanlarına rol model olmasını ve kurumunda etik kültürün oluşmasını sağlayacaktır (Bahar, 2019; Brown, Trevino ve Harrison, 2005). Bu nedenle de gelecek yüzyıldaki eğitim liderlerinin yönetsel başarıların artırılması açısından etik liderlik davranışları eğitimde kaliteyi artırmada etkili olacaktır (Duncan, 1991).

Alan yazın incelendiğinde farklı eğitim kademelerinde etik liderlik konusunu ele alan çalışmalar olduğu görülmektedir (Akdoğan ve Demirtaş, 2014; Aydın, 2002; Bahar, 2019; Erdoğdu, Umurkan ve Kuru, 2013; Ergüç, 2002; Gültekin, 2008; Gümüşeli, 2004; Karaköse, 2007; Küçükkaraduman, 2006; Tombak ve Bakan, 2014; Turhan, 2007; Yılmaz, 2006). Ancak okul öncesi kurum yöneticilerinin etik liderlik davranışlarını ele alan bir çalışmaya rastlanmamıştır. Hâlbuki eğitim kademelerinin en önemli basamağını oluşturan okul öncesi dönemde görev yapan öğretmenlerin mesleklerine ilişkin memnuniyet ve iş doyum düzeylerini, örgütsel bağlılıklarını etkileyen en önemli faktörlerden birisi yöneticilerin etik liderlik davranışlarıdır. Okul öncesi öğretmenlerinin mesleki memnuniyetlerini artırmada okul yöneticilerinin önemli rol ve sorumluluğu olduğu dikkate alındığında bu çalışmanın alan yazına katkı sağlayacağı düşünülmektedir. Ayrıca, okul öncesi eğitim kurumlar yöneticilerinin etik liderlik davranışlarının belirlenmesi, bu kademede kaliteyi etkileyen yönlerin ortaya konması açısından da oldukça önemlidir. Bu çalışmanın okul öncesi yöneticilerinin etik liderlik davranışlarını ele 
alacak ileriye yönelik araştırmalara da 1şık tutacağı düşünülmektedir. Bu nedenle araştırmada okul öncesi eğitim kurum yöneticilerinin etik liderlik davranışları ve etik liderlik davranışlarını etkileyen değişkenleri incelemek amaçlanmıştır. Bu amaç doğrultusunda aşağıdaki sorulara cevap aranmıştır;

1. Okul öncesi öğretmenlerinin, okul yöneticilerinin etik liderlik davranışlarına yönelik algıları ne düzeydedir?

2. Okul öncesi öğretmenlerinin, okul yöneticilerinin etik liderlik davranışlarına yönelik algıları yaş değişkenine göre anlamlı düzeyde farklılaşmakta mıdır?

3. Okul öncesi öğretmenlerinin yöneticilerinin etik liderlik davranışlarına yönelik algıları kıdem yılına değişkenine göre anlamlı düzeyde farklılaşmakta mıdır?

\section{Yöntem}

\section{Araştırma Modeli}

Okul öncesi eğitim kurumu okul yöneticilerinin etik liderlik davranışlarını belirlemek amacıyla yapılan bu araştırma nicel araştırma yöntemlerinden betimsel tarama modelindedir. Tarama modeli, geçmişte ya da halen var olan bir durumu var olduğu biçimiyle betimlemeyi amaçlayan araştırma yaklaşımidır (Karasar, 2005).

\section{Çalışma Grubu}

Araştırmanın çalışma grubunu 2020-2021 eğitim öğretim yılında Antalya il merkezindeki okul öncesi eğitim kurumlarında görev yapmakta olan okul öncesi öğretmenleri oluşturmaktadır. Çalışma grubu seçkisiz olmayan örnekleme yöntemlerinden uygun örnekleme yöntemi ile oluşturulmuştur. Uygun örnekleme, kısıtlı bir zaman aralığında hızlı bir şekilde veri toplanmasının gerekli olduğu çalışmalarda örneklemin evrenin kolay ulaşılabilir ve uygulama yapılabilir kesiminden seçilmesi olarak açıklanabilir (Büyüköztürk, Kıliç Çakmak, Akgün, Karadeniz ve Demirel, 2012). Veriler toplanmadan önce 
Sosyal ve Beşerî Bilimler Bilimsel Araştırma ve Yayın Etiği Kurulu'ndan izin alınmıştır. Daha sonra kişisel bilgi formu ve Etik Liderlik Ölçeği (ELÖ) Google Forma aktarılmış, katılımcılara ulaştırılmak üzere bir bağlantı oluşturulmuştur. Bahsedilen örnekleme tekniğine göre gönüllülük esasına bağlı olarak ölçme aracına eksiksiz şekilde yanıt veren 163 okul öncesi öğretmeni çalışma grubuna dahil edilmiştir. Araştırmaya katılan okul öncesi öğretmenlerinin \%38'i (n=62) 21-29 yaş; \%62'si (n=101) 30 yaş ve üstü yaş grubundadır. Katılımcıların \%51.5'i (n=84) 10 yılın altında; \%48.5'i $(n=79)$ ise 10 yılın üstünde kıdem yllına sahiptir.

\section{Veri toplama araçları}

Verilerin toplanmasında, araştırmacı tarafından hazırlanan demografik bilgi formu ve Yılmaz (2005) tarafından geliştirilen “Etik Liderlik Ölçeği” kullanılmiştır.

Demografik bilgi formu: Araştırmacı tarafından hazırlanan demografik bilgi formunda katılımcılar ile ilgili yaş, cinsiyet, kıdem yılı gibi sosyo-demografik bilgiler yer almaktadır.

Etik liderlik ölçeği (ELÖ): Okul yöneticilerinin etik liderlik davranışları gösterme düzeylerini belirlemek amaciyla Yılmaz (2005) tarafından geliştirilen “Etik Liderlik Ölçeği (ELÖ)” tamamen katılıyorum (5), katılıyorum (4), fikrim yok (3), katılmıyorum (2), kesinlikle katılmıyorum (1) şeklinde cevaplandırılan ve puanlanan 5'li Likert tipi bir ölçektir. Dört faktörden oluşan ELÖ'de birinci faktör (iletişimsel etik) varyansın \%21.525'ini (özdeğer: 8.302), ikinci faktör (iklimsel etik) \%14.208'ini (özdeğer: 5.480), üçüncü faktör (davranışsal etik) \%14.638' ini (özdeğer: 4.165) ve dördüncü faktör (karar vermede etik) ise \%10.798'ini (özdeğer: 5.646) açıklamaktadır. Ölçeğin toplam güvenirlik katsayısı .97'dir. Dört alt boyutun kendi içlerinde hesaplanan güvenirlik katsayıları, iletişimsel etik için .95, iklimsel etik için .92, davranışsal etik için .90 ve 
karar vermede etik alt boyutu için .94 olarak bulunmuştur. Ölçeğin tüm boyutlarında 44 maddenin madde-test korelasyonu .68 ile .86 arasında değişmektedir.

\section{Verilerin analizi}

Araştırma sürecinde toplanılan verilerin çözümlenmesi sürecinde öncelikle verilerin dağılımına bakılmış, çarpıklık (skewness) ve basıklık (kurtosis) değerlerinin -1.5 ile +1.5 arasında olduğu görülmüştür. Çarpıklık ve basıklık değerlerinin -1.5 ile +1.5 arasında kalması durumunda dağılımın normal olduğu kabul edildiğinden (Tabachnick and Fidell, 2013), değişkenlere ilişkin ortalamalar arasındaki farkın belirlenmesinde t-testi analizi yapılmıştır. Araştırmada okul öncesi öğretmenlerinin yöneticilerin etik liderlik davranışına ilişkin algı düzeylerini saptamak için aritmetik ortalama ve standart sapmaya bakılmıştır. Beşli ELÖ ölçeğin değer farkının (5-1), değer yargısına (5) bölünmesi ile elde edilen $0.80^{\prime}$ lik aralıklar maddelerin benimsenme düzeyinin s1nırlarını belirlemektedir. Buna göre ölçeklerden elde edilen aritmetik ortalamalar yorumlanırken 1.00-1.79 "oldukça düşük", 1.80- 2.59 "düşük", 2.603.39 "orta", 3.40-4.19 “yüksek", 4.20-5.00 aralığ 1 ise "oldukça yüksek" olarak değerlendirilmiştir.

\section{Bulgular}

Okul öncesi öğretmenlerinin okul yöneticilerinin etik liderlik davranışlarına yönelik görüşlerini belirlemek amacıyla yapılan analiz sonuçları aşağıda sunulmuştur.

Tablo 1. Etik liderlik ölçeğinden elde edilen verilere ilişkin betimsel istatistikler

\begin{tabular}{llll}
\hline $\begin{array}{l}\text { Değerlendirme Ölçeği ve Alt Boyutları } \\
(\mathbf{n}=\mathbf{1 6 3})\end{array}$ & $\overline{\mathbf{x}}$ & $\mathbf{s s}$ \\
\hline İletişimsel Etik & 2.92 & 1.34 \\
\hline İklimsel Etik & 3.01 & 1.28 \\
\hline
\end{tabular}




\begin{tabular}{lll}
\hline Davranışsal Etik & 2.99 & 1.34 \\
\hline Karar Vermede Etik & 2.97 & 1.34 \\
\hline ELÖ Genel & 2.97 & 1.29 \\
\hline
\end{tabular}

Tablo 1 incelendiğinde okul öncesi öğretmenlerinin yöneticilerin etik liderlik rollerine ilişkin İletişimsel Etik ( $\bar{x}=2.92)$, İklimsel Etik ( $\bar{x}=3.01)$, Davranışsal Etik ( $\bar{x}=2.99)$, Karar Vermede Etik ( $\bar{x}=2.97)$, ELÖ Genel ( $\bar{x}=2.97)$ puan ortalamalarının orta seviyede olduğu görülmektedir.

Tablo 2. Okul öncesi öğretmenlerinin ELÖ genelindeki ve alt boyutlarındaki görüş düzeylerinin yaş değişkenine göre farklılığına yönelik $t$-testi sonucu

\begin{tabular}{|c|c|c|c|c|c|c|}
\hline \multicolumn{7}{|c|}{ Ölçeğin Boyutlan } \\
\hline$(n=163)$ & Yaş & $\mathbf{n}$ & $x^{-}$ & ss & $\mathbf{t}$ & $\mathbf{p}$ \\
\hline \multirow[t]{2}{*}{ İletişimsel Etik } & $21-30$ & 62 & 2.59 & 1.33 & -2.493 & .014 \\
\hline & $30+$ & 101 & 3,12 & 1.31 & & \\
\hline \multirow[t]{2}{*}{ İklimsel Etik } & $21-30$ & 62 & 2.75 & 1.30 & -2.026 & .044 \\
\hline & $30+$ & 101 & 3.16 & 1.25 & & \\
\hline \multirow[t]{2}{*}{ Karar Vermede Etik } & $21-30$ & 62 & 2.63 & 1.33 & -2.804 & .000 \\
\hline & $30+$ & 101 & 3.22 & 1.30 & & \\
\hline \multirow[t]{2}{*}{ Davranışsal Etik } & $21-30$ & 62 & 2.66 & 1.37 & -2.395 & .018 \\
\hline & $30+$ & 101 & 3.17 & 1.30 & & \\
\hline \multirow[t]{2}{*}{ ELÖ Geneli } & $21-30$ & 62 & 2.65 & 1.30 & -2.486 & .014 \\
\hline & $30+$ & 101 & 3.16 & 1.26 & & \\
\hline
\end{tabular}

Tablo 2 incelendiğinde okul öncesi öğretmenlerinin yöneticilerin etik liderlik algılarında yaş değişkenine göre anlamlı farklılıklar olduğu (t=-2.486, p<.05) görülmektedir. 30 yaş ve üzeri öğretmenlerin 30 yaş altındaki öğretmenlere göre okul yöneticilerinin iletişimsel etik ( $\mathrm{t}=-2.493, \mathrm{p}<.05)$, iklimsel etik $(t=-2.026, p<.05)$, karar vermede etik $(t=-2.804, p<.05)$ ve davranışsal etik $(t=-2.395, p<.05)$ davranışlarını daha fazla sergilediğine ilişkin görüşe sahip oldukları görülmektedir. 
Tablo 3. Okul öncesi öğretmenlerinin ELÖ genelindeki ve alt boyutlarındaki görüş düzeylerinin kıdem yılına göre farklılı̆̆ına yönelik T testi sonucu

\begin{tabular}{|c|c|c|c|c|c|c|}
\hline \multicolumn{7}{|l|}{ Ölçeğin } \\
\hline Boyutları (n=163) & Kidem yilı & $\mathbf{n}$ & $\bar{x}$ & ss & $t$ & $\mathbf{p}$ \\
\hline \multirow[t]{2}{*}{ İletişimsel Etik } & $1-10$ yıl & 84 & 2.61 & 1.31 & -3.104 & .002 \\
\hline & +10 yll & 79 & 3.25 & 1.30 & & \\
\hline \multirow[t]{2}{*}{ İklimsel Etik } & $1-10$ yll & 84 & 2.72 & 1.32 & -3.043 & .003 \\
\hline & +10 yil & 79 & 3.31 & 1.17 & & \\
\hline \multirow[t]{2}{*}{ Karar Vermede Etik } & $1-10$ yil & 84 & 2.63 & 1.33 & -3.673 & .000 \\
\hline & +10 yll & 79 & 3.38 & 1.24 & & \\
\hline \multirow[t]{2}{*}{ Davranışsal Etik } & $1-10$ yll & 84 & 2.66 & 1.35 & -3.193 & .002 \\
\hline & $+10 \mathrm{yll}$ & 79 & 3.31 & 1.25 & & \\
\hline \multirow[t]{2}{*}{$\overline{\text { ELÖ Geneli }}$} & $1-10$ yll & 84 & 2.65 & 1.30 & -3.310 & .001 \\
\hline & +10 yıl & 79 & 3.30 & 1.21 & & \\
\hline
\end{tabular}

Tablo 3'e göre 10 yılın üzerinde mesleki deneyime sahip olan öğretmenlerin ELÖ alt boyutları olan iletişimsel etik $(\mathrm{t}=-3.104, \mathrm{p}<.05)$, iklimsel etik $(\mathrm{t}=$ 3.043, $\mathrm{p}<.05)$, karar vermede etik $(\mathrm{t}=-3.673, \mathrm{p}<.05)$ ve davranışsal etik $(\mathrm{t}=$ 3.193, $\mathrm{p}<.05)$ boyutlarındaki görüş düzeyleri ile ELÖ genelindeki $(t=-3.310$, $p<.05)$ görüş düzeylerinin 1-10 yıl arasında mesleki deneyime sahip olan öğretmenlere göre anlamlı şekilde daha yüksek olduğu görülmektedir.

\section{Tartışma ve Sonuç}

Okul öncesi eğitim kurumlarında görev yapan öğretmenlerin bakış açısıyla kurum yöneticilerinin etik liderlik davranışlarını incelemek amacıyla yapılan bu çalışmada elde edilen ana bulgu okul öncesi eğitim kurumu yöneticilerinin orta düzeyde etik liderlik davranışları sergilediği yönündedir. Bu sonuca göre, okul öncesi eğitim kurumlarında görev alan yöneticilerinin etik liderlik temelinde yönetsel davranışlarında eksiklikleri olduğunu söylemek mümkündür. Alan yazın incelendiğinde farklı eğitim kademelerinde öğretmenlik yapan çalışanların kurum yöneticilerinin yüksek/yeterli düzeyde etik liderlik davranışları sergilediğine ilişkin çalışmalara rastlanmaktadır (Acar ve Kaya, 
2012; Baştuğ, 2009; Erdoğan, 2007; Gültekin, 2008; Helvac1, 2010; Karagöz, 2008). Araştırmalar okul müdürünün duruşu, bilgisi, becerisi, karakter yapısı ve davranışlarıyla ortaya koyduğu etkili yönetim becerilerinin ve etik liderlik davranışlarının örgüt üyelerini olumlu yönde etkilediğini ortaya koymaktadır (Velasquez and Velasquez, 2002; Yılmaz, 2005). Öğretmenlerin enerjilerini, potansiyel güçlerini okulun amaçları doğrultusunda kullanmaları ve mesleğini severek iş doyum düzeylerinin artmasında çalıştıkları okula bağlı olmaları önemli bir etkendir (Zeren, 2007). Bu bağlamda okul öncesi eğitim kurumlarında yöneticilik yapan liderlerin etik liderlik davranışları geliştirmelerine yönelik destekleyici çalışmalara gereksinim olduğu düşünülmektedir.

Araştırmadan elde edilen ikinci önemli sonuç, öğretmenlere göre kurum yöneticilerinin iletişimsel etik, iklimsel etik, karar vermede etik ve davranışsal etik davranışlarının da orta seviyede olduğudur. Alan yazında bu bulguyu destekleyen araştırma sonuçları görülebildiği gibi çelişen araştırma sonuçları da görülmektedir. Örneğin; Uğurlu (2012) ilköğretim yöneticilerinin oldukça yüksek düzeyde iletişimsel etik davranışlar sergilediğini belirtirken, Celep (1992) çalışmasında ilkokul yöneticilerinin iletişimsel davranışlarda konumlarından gelen gücü hissettirme ve öğretmenlerle aralarına bir sınır koyma davranışları sergilediklerini bulmuştur. Çalışmanın bu sonucu, okul öncesi eğitim kurumu yöneticilerinin çalışma ortamında hatalarını kabul etme, tartışmalara tarafsız ve anlayışlı bir şekilde yaklaşma, çalışanlara eşit davranma, alçak gönüllü olma, sabırlı davranma, merhametli olma, çalışanlar arasında arabulucu olma gibi iletişimsel etik davranışları sergileme başarısının, okul öncesi öğretmenlerinin beklediği düzeyde olmadığını göstermektedir. Bu bağlamda çalışmaya katılan okul öncesi öğretmenlerinin, potansiyel güçlerini sergilemede yöneticilerinden iletişimsel etik liderliği davranışlarına gereksinim duydukları söylenebilir. Okul yöneticilerinin öğretmenlerin sorunlarını algılaması, sorunlara çözüm üretme konusunda duyarlı olmaları, kurumda çalışan öğretmenlerin kurumun hedeflerini benimsenme- 
sini kolaylaştırmakta ve üretkenliği artırmaktadır (Zeren, 2007). Eğitim kurumunda lider olan yönetici ile öğretmenler arasındaki olumlu iletişim ve iş birliği, kurumun eğitsel başarısını ve eğitim paydaşı olan öğretmenin iş doyumunu artıran en önemli unsurlardan biridir (Çetinkanat, 2000). Bu açıdan bakıldığında öğretmen ile yönetici arasında kurulan iletişimsel etik davranışlarının güçlenmesi öğretmenlerin kuruma bağlllık düzeylerini etkileyecek, dolayısı ile de kurum yöneticisine ve kurumuna güven duygusunu arttıracaktır.

Okul öncesi eğitimi kurum yöneticilerinin iklimsel etik davranışlarının da orta düzeyde olduğu sonucuna ulaşılmıştır. Bu sonuç okul öncesi öğretmenlerin kurum yöneticilerini, mesleki performanslarını artırma, meslektaşlarının farklılıklarına saygı gösterme, geleceğe yönelik hedeflerde somut olma ve sevgiyi temel alma gibi iklimsel etik davranışlarında yeterli görmediklerini göstermektedir. Helvacı'nın (2010) ve Acar ve Kaya'nın (2012) çalışmasında da iklimsel etik ile ilgili aynı sonuçlara vurgu yapılmaktadır. Uğurlu'nun (2012) çalışmasında ise okul yöneticilerinin iklimsel etik davranışlarının oldukça yüksek olduğu belirtilmektedir. Çalışmalardan elde edilen farklı sonuçların nedeni her öğretim kademesindeki öğretmenlerin yöneticilerinden beklentilerinin farklı olmasından kaynaklı olabilir. Velasquez ve Velasquez (2002) etik liderlik davranışlarına sahip yöneticilerin öncelikli amaçları arasında kurum çalışanlarının duygusal bağllıklarını artırıcı okul iklimi yaratmak olduğunu belirtmektedir. Liderlerin yönetsel olarak aldıkları kararlar ve uygulamalarda güçlerini nasıl kullandıklarıyla ilgili bir kavram olan etik liderlik (Akdoğan ve Demirtaş, 2014), çalışanlarının haklarına ve onuruna saygilı bir şekilde liderlik etmeyi ifade etmektedir (Ciulla, 2004). Etik liderlik davranışları sergilenen bir kurumda, sağlıklı ve destekleyici bir okul iklimi oluşur. Oluşan bu okul ikliminde eşitlik, adalet, duyarlılık temelinde inşa edilmiş olur (Haynes, Emons ve Ben-Avie, 1997). Bu açıdan bakıldığında okul öncesi eğitim kurumlarındaki yöneticilerin özellikle eğitime ilişkin kararlarda öğretmenlere yönelik yönetsel davranışlarında eşit ve adaletli davran- 
maları, öğretmenlerin okul yöneticilerine duydukları güveni artırarak (Cemaloğlu ve Kılınç, 2012) çalışma motivasyonlarını olumlu yönde etkileyecektir.

Araştırmadan elde edilen bir diğer sonuç ise okul öncesi kurum yöneticilerinin karar vermede etik davranışlarının orta düzeyde olduğu yönündedir. Bu sonuç araştırmaya katılan okul öncesi öğretmenlerinin kurum yöneticilerini bireysel kazanç sağlamaya yönelik davranışlarda bulunmama, kötü alışkanlıklardan uzak durma, dini kötü amaçlarla kullanmama ve sistematik bir yaklaşımla problemlere çözüm üretme gibi etik liderlik davranışlarını göstermede yeterli görmediklerini ortaya koymaktadır. Helvacı (2010) da çalışmasinda benzer bir bulguya ulaşarak ilköğretim okulu yöneticilerinin karar vermede etik davranışlarının orta seviyede olduğunu tespit etmiştir. Öte yandan Baştuğ (2009) ve Uğurlu (2012) ise çalışmalarında tersi bir sonuca ulaşarak okul yöneticilerinin karar vermede etik davranışlarının yüksek düzeyde olduğunu belirtmiştir. Etik olmayan lider davranışlarının çalışanlar arasında işbirliği, iletişim, yaratıcılık, huzur ve güveni yok ettiği (Alatlı, 1999) düşünüldüğünde okul öncesi eğitim kurumlarında görev yapan yöneticilerin etik liderliğin karar verme boyutunda öğretmenlerin beklentilerini karşılamada ve çalışanlar arasında iletişim, işbirliği gibi performansı artırıcı etkenleri sağlamada yeterli olmadıklarını söylemek mümkündür.

Araştırma sonucunda okul öncesi eğitim kurumu yöneticilerinin etik davranışlar sergilemede orta düzeyde olduğu belirlenmiştir. Bu sonuç okul öncesi öğretmenlerin kurum yöneticilerini, doğru sözlü olma, dürüst olma, insanların haklarını savunma, kendini eleştirebilme ve içinde bulunduğu topluma ve kültüre saygı gösterme gibi davranışlarda yeterli görmediklerini ortaya koymaktadır. Araştırmadan elde edilen bu sonuca paralel olarak Helvacı (2010) da çalışmasında ilköğretim kurum yöneticilerinin orta düzeyde etik davranışlar gösterdiği sonucuna ulaşmıştır. Öte yandan Baştuğ (2009) ise çalışmasında okul yöneticilerinin yüksek düzeyde etik davranışlar gösterdiklerini tespit etmiştir. Araştırmadan elde edilen bu sonuca dayanarak okul ön- 
cesi yöneticilerinin örgüt kültürünün oluşmasında oldukça önemli olan çallşanların haklarının savunulması, dürüst olma gibi önemli etik ilkelerin gösterilmesinde okul öncesi öğretmenlerinin beklentilerini karşılayamadıkları söylenebilir. Hâlbuki öğretmenlerin potansiyel gücünü açığa çıarmada yöneticilerin öğretmenlerin sorunlarını dinlemesi, anlaması, problemlere çözüm üretmesi, kısacası çalışanlar ile iyi ilişkiler içerisinde olması çok önemlidir.

Araştırmadan elde edilen bir diğer sonuç okul öncesi öğretmenlerinin kurum yöneticilerinin iletişimsel, iklimsel, karar verme ve davranışsal etik liderlik rollerine ilişkin algılarının yaş değişkenine göre 30 yaş ve üzerindeki kattlımclar lehine farklılaştığı yönündedir. Bu sonuca göre 30 yaş ve üzeri öğretmenler yöneticilerin hatalarını kabul etme, tartışmalara tarafsız ve anlayışı bir şekilde yaklaşma, çalışanlar arası farklılıklara saygı gösterme, eşit davranma ve ayrımcllı yapmama, sorumluluk duygusuna sahip olma, kötü alışkanlıklardan uzak durma, bencil davranmama, inancı kötü amaçlarla kullanmama, dürüst olma, kendini eleştirebilme gibi etik davranışlarda orta düzeyde de olsa yeterli olduğunu düşünmektedir. 30 yaş altındakiler ise yöneticilerinin belirtilen etik liderlik becerilerinde yetersiz olduğunu düşünmektedir. Tombak ve Bakan (2014) da çalışmasında 40-49 yaş aralığındaki öğretmenlerin yöneticilerini etik liderlik bağlamında yeterli olduğunu ifade ettikleri sonucuna ulaşmışlardır. Uğurlu (2012) ise çalışmasında öğretmen yaşı arttıkça yönetici ile öğretmen arasındaki iletişimsel davranışların daha pozitif algılandığını belirlemiştir. Bu sonuçlardan yola çıkarak çalışan yaşı ilerledikçe kurum yöneticileri ile kurulan etkileşimin daha pozitif olarak algılandığı söylenebilir. Yaş arttıkça yönetici davranışlarının daha pozitif olarak algılanmasının nedeni yöneticilerin belli bir yaşa erişmiş öğretmenlere karşı daha hoşgörülü ve toleranslı davrandıklarını akla getirmektedir. Bununla birlikte daha gençöğretmenlerin yönetsel beklentilerinin yaş almış öğretmenlerden daha farklı olduğu da düşünülebilir.

Araştırmadan elde edilen bir diğer bulguya göre yöneticilerinin etik liderlik davranışlarına ilişkin algıda öğretmenlerin kıdem süresinin etkili olduğu 
ve kıdem süresi arttıkça yöneticilere ilişkin etik davranış algılarının daha pozitif olduğudur. Bu bağlamda okul öncesi öğretmenlerin yöneticilerinin davranışlarını anlamlandırmalarına ilişkin algılarında mesleki kıdemin farklılık yarattı̆ııı söylemek mümkündür. Erdoğdu, Umurkan ve Kuru'nun (2013) çalışmasında da kıdemi süreleri arttıkça öğretmenlerin yöneticilerin etik liderlik davranışlarına ilişkin algılarının daha olumlu olduğu belirlenmiştir. Küçükkaraduman (2006) ve Tombak ve Bakan'ın (2014) çalışmalarında da benzer bir sonuçlara ulaşılmış, mesleki kıdem artıkça öğretmenlerin yöneticilerini etik ilkeleri yansıtma konusunda daha olumlu algıladıkları sonucuna ulaşılmıştır. Bu sonuçlardan hareketle öğretmenlerin mesleki kıdem yılı arttıkça okul yöneticileri ile iletişimlerinin arttı̆ğ, buna bağlı olarak da karşılıklı hoşgörü ve anlayış çerçevesinde ilişkilerin şekillendiği şeklinde yorumlanabilir. Araştırmadan elde edilen bu sonuca göre mesleki deneyimin, yöneticilerinin davranışlarını anlamlandırmaları ve davranış beklentileri konusunda öğretmen algılarında farklılık yarattığını söylemek mümkündür. Ancak Gültekin (2008), Oğuz (2011) ve Yücel'in (2019) yapmış oldukları çalışmalarda yöneticilerin liderlik stillerine yönelik öğretmen algılarında kıdemin etkili bir değişken olmadığı belirtilmektedir.

Sonuç olarak, okul öncesi eğitim kademesinde görev alan yöneticilerin eğitimde etik liderlik davranışlarını benimsemelerinin oldukça önemli olduğu söylenebilir. Liderlik becerilerinin sonradan öğretilebilir olması nedeniyle (Garcia, 2003; Sternberg, 2005) okul öncesi kurumlarda görev yapan yöneticilerin etik liderlik becerileri boyutunda hizmet içi eğitimlere tabi tutulmalarının öğretmenlerin motivasyonu ve çalışma verimliliğini artırarak okul öncesi eğitim kurumlarının başarısına olumlu etkisi olacağı düşünülmektedir. Bu bağlamda okul öncesi kademede görev yapan yöneticilerin etik liderlik davranışlarının önemi ve gerekliliğine ilişkin farkındalıklarının artırılması yönünde hizmet içi eğitimler düzenlenebilir, seminer ve konferans gibi etkinliklere katılımları sağlanabilir. 


\title{
EXTENDED ABSTRACT
}

\section{Ethical Leadership Behaviors of Preschool Managers According to Teacher Perceptions: Case of Antalya}

\author{
Begümhan Yüksel \\ Akdeniz University
}

Early childhood is critical because it is the period in which children between the ages of 0-8 show rapid development, their learning capacity is the highest, and their personality traits are shaped. In this period, preschool teachers who take an active role in the education they receive in pre-school education institutions, as well as families, have a great influence on the development of children. In this context, it is possible to say that the professional motivation and satisfaction levels of preschool teachers are a factor that affects the quality of preschool education. Studies (Çetin, 2016; Demirtaş ve Akdoğan, 2015; Gülcan, Kılınç ve Çepni, 2012; Güllü, 2009; Neubert, Carlson, Kacmar, Roberts and Chonko, 2009; RuizPalomino, Ruiz-Amaya and Knörr, 2011) show that one of the most important factors affecting their satisfaction, work performance and commitment to their institutions is their ethical leadership behavior.

Managers should have universal ethical values such as respect for the rights and dignity of others, democratic management understanding, and strong communication while making decisions about the operation of the institution and putting their decisions into practice (Ciulla, 2004; Y1lmaz, 2008). Yilmaz (2005) discussed the ethical leadership levels of school administrators in four groups: communicative ethics, climatic ethics, decision-making ethics, and behavioral ethics.

When the literature is examined, there are studies dealing with ethical leadership at different educational levels (Akdoğan ve Demirtaş, 2014; Aydın, 2002; Bahar, 2019; Erdoğdu, Umurkan ve Kuru, 2013; Ergüç, 2002; Gültekin, 2008; Gümüşeli, 2004; Karaköse, 2007; Küçükkaraduman, 2006; Tombak and Bakan, 2014; Turhan, 2007; Yılmaz, 2006). However, no study has been found that deals with the ethical leadership behaviors of preschool administrators. However, one of the most important factors affect- 
ing the professional satisfaction and job satisfaction levels and organizational commitment of the pre-school teachers, which constitute the most important step of the education levels, is the ethical leadership behaviors of the administrators. Considering that school administrators have an important role and responsibility in increasing the professional satisfaction of preschool teachers, this study aims to examine the ethical leadership behaviors of institution administrators working in preschool education institutions.

163 teachers working in pre-school education institutions in the city center of Antalya in the 2020-2021 academic year were included in this research carried out in the descriptive survey model. Demographic information form and "Ethical Leadership Scale" were used to collect data in the study. In the analysis of the data, the arithmetic mean and standard deviation were examined in order to determine the perception levels of the preschool teachers regarding the ethical leadership behavior of the administrators, and the t-test analysis was performed to determine the difference between the means for age and professional seniority variables.

According to the first finding obtained from the research, Communicative Ethics $(\bar{x}=2.92)$, Climatic Ethics $(\bar{x}=3.01)$, Behavioral Ethics $(\bar{x}=2.99)$, Ethics in Decision Making $(\bar{x}=2.97)$, ELÖ General $\bar{x}=2.97)$ mean scores were found to be at a medium level. According to another finding obtained from the research, it was determined that there are significant differences in the ethical leadership perceptions of the preschool teachers according to the age variable $(\mathrm{t}=-2.486, \mathrm{p}<.05)$ and professional seniority $(\mathrm{t}$ $=-3.310, \mathrm{p}<.05$ ).

As a result of the research, it was determined that administrators working in preschool education institutions have moderate ethical leadership behaviors in the context of communicative ethics, climatic ethics, ethics in decision making and behavioral ethics. According to this result, it is possible to say that administrators working in preschool education institutions have deficiencies in managerial behaviors based on ethical leadership. When the literature is examined, there are studies showing that the managers of the institutions who work as teachers at different educational levels exhibit high / sufficient level of ethical leadership behavior (Acar ve Kaya, 2012; Baştuğ, 2009; Erdoğan, 2007; Gültekin, 2008; Helvac1, 2010; Karagöz, 2008). It is an important factor that teachers use their energies and 
potential powers in line with the goals of the school and that they love their job and are attached to the school they work in to increase their job satisfaction (Zeren, 2007). In this context, it is thought that the leaders who are administrators in preschool education institutions need supportive studies to develop ethical leadership behaviors.

According to another result obtained from the study, it was determined that there are significant differences in the ethical leadership behaviors of administrators according to the perceptions of preschool teachers according to the age variable and this difference is in favor of teachers over the age of 30. According to this result, teachers aged 30 and over think that institution administrators are sufficient in ethical behavior, albeit at a moderate level. Those under the age of 30 think that their managers are insufficient in the stated ethical leadership skills. The reason why administrators' behaviors are perceived more positively as age increases suggests that administrators behave more indulgent and tolerant towards teachers who have reached a certain age. However, it can be thought that the managerial expectations of younger teachers are different from those of older teachers. When the literature is examined, studies reveal that as the age of the teacher increases, the communication with the institution administrators is perceived more positively (Tombak ve Bakan, 2014; Uğurlu, 2012). Based on these results, it can be said that as the age of the employee gets older, the interaction with the institution managers is perceived as more positive.

It was determined that the seniority period of the teachers was also effective in the perception of the administrators' ethical leadership behaviors and the higher the seniority, the more positive the perceptions of ethical behavior towards the administrators. In this context, it is possible to say that professional seniority makes a difference in preschool teachers perceptions of their administrators making sense of their behavior. When the literature is examined, there are studies that have reached the conclusion that as professional seniority increases, teachers perceive their administrators more positively in reflecting ethical principles (Erdoğdu, Umurkan, ve Kuru, 2013; Küçükkaraduman, 2006; Tombak and Bakan, 2014). Based on these results, it can be interpreted that as the professional 
seniority of teachers increases, their communication with school administrators increases, and accordingly, relationships are formed within the framework of mutual tolerance and understanding.

In conclusion, it can be said that it is very important for administrators who work at the pre-school education level to adopt ethical leadership behaviors in education. In this context, in-service trainings can be organized in order to increase the awareness of the administrators working at the preschool level regarding the importance and necessity of ethical leadership behaviors, and they can participate in activities such as seminars and conferences.

\section{Kaynakça / References}

Acar, G. ve Kaya, M. (2012). Okul yöneticilerinin etik liderlik davranışlarına ilişkin beden eğitimi öğretmenlerinin görüşleri. Selçuk Üniversitesi Beden Eğitimi ve Spor Bilim Dergisi, 14(1), 95-102.

Akdoğan, A. ve Demirtaş, Ö. (2014). Etik liderlik davranışlarının etik iklim üzerindeki etkisi: örgütsel politik algılamaların aracı rolü. Afyon Kocatepe Üniversitesi İktisadi ve İdari Bilimler Fakültesi Dergisi, 16(1), 107124.

Alatlı, A. (1999). Schrödinger'in kedisi. İstanbul: Boyut Yayınevi.

Aydın, İ.P. (2002). Yönetsel, mesleki ve örgütsel etik. Ankara: Pegem A Yayıncilik.

Bahar, B. (2019). Etik liderliğin çalışanlar ve örgütler açısından sonuçları: Kavramsal bir inceleme. OPUS-Uluslararası Toplum AraştırmalarıDergisi, 11(18), 2506-2524. DOI: 10.26466/opus.553130

Bandura, A. and Walters, R. H. (1986). Social learning theory. Englewood Cliffs, NJ: Prentice-hall.

Baştuğ, İ. (2009). İlköğretim okulu yöneticilerinin etik davranışlarına ilişkin öğretmen görüşleri (Konya ili örneği). (Yayımlanmamış Yüksek Lisans Tezi). Selçuk Üniversitesi Sosyal Bilimler Enstitüsü, Konya.

Bridge, B. (2003). Eğitimde vizyoner liderlik ve etkin yöneticilik. İstanbul: Beyaz Yayınları.

Brown, M. E. and Treviño, L. K. (2006). Ethical leadership: A review and future directions. The leadership quarterly, 17(6), 595-616. 
Brown, M. E., Treviño, L. K. and Harrison, D. A. (2005). Ethical leadership: A social learning perspective for construct development and testing. Organizational behavior and human decision processes, 97(2), 117-134.

Büyüköztürk, Ş., Çakmak, E. K., Akgün, Ö. E., Karadeniz, Ş. ve Demirel, F. (2012). Bilimsel araştırma yöntemleri (13.bs.). Ankara: Pegem yayınclık.

Cemaloğlu, N. ve Kılınç, A. Ç. (2012). İlköğretim okulu yöneticilerinin etik liderlik davranışları ile öğretmenlerin algıladıkları örgütsel güven ve yıldırma arasındaki ilişki. Eğitim ve Bilim, 37(165), 137-151.

Ciulla, B. J. (2004). Ethics and leadership effectiveness. J. Antonakis, A.T. Cianciolo and R. J. Sternberg (Ed.). The nature of leadership içinde (s. 302-327). London: Sage.

Çelik, V. (2012). Eğitimsel liderlik. Ankara: Pegem A Yayıncllık.

Çetin, D. (2016). Okul yöneticilerinin etik liderlik davranışlarının öğretmenlerin iş doyumu ile ilişkisi. (Yayımlanmamış yüksek lisans tezi). Zirve Üniversitesi, Gaziantep.

Çetinkanat, C. (2000). Örgütlerde güdülenme ve iş doyumu. Ankara: Anı Yayıncilik.

Demirtaş, Ö. ve Akdoğan, A. (2015). The effect of ethical leadership behavior on ethical climate, turnover intention, and affective commitment. Journal of Business Ethics, 130(1), 59-67.

Erdoğan, Ç. (2007). İlköğretim okulu müdürlerinin etik liderlik davranışları. (Yayımlanmamış yüksek lisans tezi). Yıldız Teknik Üniversitesi, İstanbul.

Erdoğdu, M., Umurkan, F. ve Kuru, T. (2013). Okul yöneticilerinin etik liderlik rolleri ile kurum imajı arasındaki ilişkiler. IZU Sosyal Bilimler Dergisi, 2(3), 37-54.

Ergüç, N. (2002). Ilköğgretim müfredat laboratuvar okulları müdürlerinin mesleki etik ilkelere iliş̧kin davranışları. (Yayınlanmamış Yüksek Lisans Tezi). Hacettepe Üniversitesi, Ankara.

Garcia, V. C. (2003). A case study of a holistic model for the professional development of school administration. (A Dissertation Submitted in Partial Fulfillment of the Requirements for the Degree of Doctor of Education). University of New Mexico, Albuquerque: New Mexico.

Gülcan, M., Kılınç, A. ve Çepni, O. (2012). İlköğretim okulu müdürlerinin etik liderlik davranışları gösterme düzeylerinin çeşitli değişkenler açısından incelenmesi. Türk Ĕ̆itim Bilimleri Dergisi, 10(1), 123-142. 
Güllü, E. (2009). Simı öğretmenlerinin algılarına göre ilköğretim okulu yöneticilerinin liderlik stilleri ile öğretmenlerin iş doyumu düzeyleri arasındaki ilişki. (Yayımlanmış yüksek lisans tezi). Gazi Üniversitesi, Eğitim Bilimleri Enstitüsü, Ankara.

Gültekin, M. (2008). Ilköğretim okulu yöneticilerinin etik liderlik davranışı gösterme düzeylerinin çeşitli değgişkenler açısından incelenmesi. (Yüksek Lisans Tezi). Selçuk Üniversitesi Sosyal Bilimler Enstitüsü, Konya.

Gümüsşeli, A. İ. (2004). Okul müdürlerinin öğretim liderliğini sınırlayan etmenler. Eğitim Yönetimi, 2(2), 23-34.

Haynes, N. M., Emmons, C., and Ben-Avie, M. (1997). School climate as a factor in student adjustment and achievement. Journal of educational and psychological consultation, 8(3), 321-329.

Helvacı, M. A. (2010). İlköğretim okulu yöneticilerinin etik liderlik davranışı gösterme düzeyleri. Zeitschrift für die Welt der Türken/Journal of World of Turks, 2(1), 391-410.

Karagöz, A. (2008). Illk ve orta öğretim okulu müdürlerinin öğretmenler tarafindan algılanan etik liderlik rolleri ile öğretmenlerin örgütsel adanmışlıkları arasındaki iliş̧ki (Bursa ili örneği). (Yayımlanmamış yüksek lisans tezi), Yeditepe Üniversitesi, İstanbul.

Karaköse, T. (2007). Okul yöneticilerinin etik liderliği. Çağdaş Ĕ̆itim, 32(338), 25-30.

Karasar, N. (2005). Bilimsel araştırma yöntemi. Ankara: Nobel Yayın Dağıtım.

Küçükkaraduman, E. (2006) İlköğretim okul müdürlerinin etik davranışlarının incelenmesi. (Yayımlanmamış Yüksek Lisans Tezi), Gazi Üniversitesi, Ankara.

Mayer, D. M., Kuenzi, M., Greenbaum, R., Bardes, M. and Salvador, R. B. (2009). How low does ethical leadership flow? Test of a trickledown model. Organizational behavior and human decision processes, 108(1), 113.

Mendonca, M. (2001). Preparing for ethical leadership in organizations. Canadian Journal of Administrative Sciences/Revue Canadienne des Sciences de l'Administration, 18(4), 266-276.

Moorhouse, J. R. (2002). Desired characteristics of ethical leaders in business educational political and religious organization from East Tennessee (Unpublished doctoral dissertation). East Tennnessee State University, Tennessee. 
Neubert, M. J., Carlson, D. S., Kacmar, K. M., Roberts, J. A. and Chonko, L. B. (2009). The virtuous influence of ethical leadership behavior: Evidence from the field. Journal of Business Ethics, 90(2), 157-170.

Oğuz, E. (2011). Öğretmenlerin örgütsel vatandaşlık davranışları ile yöneticilerin liderlik stilleri arasındaki ilişki. Kuram ve Uygulamada Eğitim Yönetimi, 17(3), 377-403.

Resick, C. J., Hanges, P. J., Dickson, M. W. and Mitchelson, J. K. (2006). A crosscultural examination of the endorsement of ethical leadership. Journal of Business Ethics, 63(4), 345-359.

Ruiz-Palomino, P., Ruiz-Amaya, C. and Knörr, H. (2011). Employee organizational citizenship behaviour: The direct and indirect impact of ethical leadership. Canadian Journal of Administrative Sciences/Revue Canadienne des Sciences de l'Administration, 28(3), 244-258.

Tabachnick B. G. and Fidell L.S. (2013) Using multivariate statistics. (6th edition). Boston: Pearson.

Tombak, N. ve Bakan, H. (2014). Illköğretim okulu yöneticilerinde etik liderlik: Muğla ili örneği. Mŭ̆la Üniversitesi Sosyal Bilimler Enstitüsü Dergisi, (32), 95-121.

Turhan, M. (2007). Genel ve mesleki lise yöneticilerinin etik liderlik davranışlarının okullardaki sosyal adalet üzerindeki etkisi. (Yayımlanmamış Doktora Tezi). Furat Üniversitesi, Elâzı ğ.

Uğurlu, C. (2012). İlköğretim okulu öğretmenlerinin yönetici etik liderlik davranışına ilişkin algıları. Cumhuriyet Üniversitesi Edebiyat Fakültesi Sosyal Bilimler Dergisi, 36(2), 203-213.

Velasquez, M. G., and Velazquez, M. (2002). Business ethics: Concepts and cases. Upper Saddle River, NJ: Prentice Hall.

Wekesser, C. (1995). Ethics. San Diego, CA: Greenhaven Pres.

Yılmaz, E. (2005). Okullarda örgütsel güven ölçeğinin geçerlilik ve güvenirlik çalışması. Selçuk Üniversitesi Sosyal Bilimler Enstitüsü Dergisi, 14, 739756.

Yılmaz (2006). Okullardaki örgütsel güven düzeyinin okul yöneticilerinin etik liderlik özellikleri ve bazı değişkenler açısından incelenmesi. (Yüksek Lisans Tezi). Selçuk üniversitesi, Sosyal Bilimler Enstitüsü, Konya.

Yılmaz, K. (2008). Ĕ̆itim yönetiminde değerler. Ankara: Pegem A Yayıncılık.

Yücel, B. G. (2019). Okul öncesi yöneticilerin liderlik stilleri ile öğretmenlerin iş doyumu arasındaki ilişki. (Yüksek Lisans Tezi). İstanbul Sabahattin Zaim Üniversitesi. 
Zeren, H. (2007). İlköğretim okulu müdürlerinin dönüşümcü liderlik stilleri ile bu okullarda görevli öğretmenlerin örgütsel bağhliı̆̆ arasındaki ilişki. (Yayımlanmamış yüksek lisans tezi). Harran Üniversitesi, Şanlıurfa.

\section{Kaynakça Bilgisi / Citation Information}

Yüksel, B. (2021). Öğretmen algılarına göre okul öncesi yöneticilerinin etik liderlik davranışları: Antalya ili örneği. OPUS-Uluslararası Toplum Araştırmaları Dergisi, 17(37), 4824-4846. DOI: 10.26466/opus. 892148 